\title{
THE INFLUENCE OF LEACHATE REAGENTS ON HYDROMETALLURGICAL RECOVERY OF METALS FROM SPENT PCBS
}

\author{
${ }^{1}$ Magdalena LISIŃSKA, ${ }^{1}$ Mariola SATERNUS, ${ }^{2}$ Silvie BROŽOVÁ \\ ${ }^{1}$ Silesian University of Technology, Katowice, Poland, EU, \\ magdalena.lisinska@polsl.pl, mariola.saternus@polsl.pl \\ ${ }^{2}$ VSB - Technical University of Ostrava, Ostrava, Czech Republic, EU, silvie.brozova@vsb.cz
}

https://doi.org/10.37904/metal.2019.937

\begin{abstract}
For several years, continuous technological progress has been observed, resulting in a constantly growing number of e-waste. The diversified composition of e-waste causes the emergence of a large amount of hazardous waste, which is a threat to both health and life of people, as well as the environment. Nowadays, effective recycling of this type of waste has been recognized as a major challenge for every society. Spent printed circuit boards (PCBs) that are part of most electronic devices, including mobile phones and computers contain many metals. Printed circuit boards cause not only ecological threat, but also serious waste of resources, including copper. That is why new and effective ways to process these wastes and re-use of recovered metals are increasingly investigated. Interest in hydrometallurgical processing of used electronic equipment has increased in recent years due to its advantages - it is more accurate, more predictable and easier to control compared to pyrometallurgical methods. This method does not require the use of complicated and expensive devices. There are many leaching reagents that allow the dissolution of metals. Among the appropriate leaching agents, acids such as $\mathrm{H}_{2} \mathrm{SO}_{4}, \mathrm{HCl}$ and $\mathrm{HNO}_{3}$ can be distinguished. Literature data show that a strong oxidizing agent should be used to increase the efficiency of the leaching process. This is justified by presented in the literature results of leaching with the addition of hydrogen peroxide and ozone. Own research confirms that among the best leaching agents the best results of copper leaching from electronic waste were obtained for $\mathrm{H}_{2} \mathrm{SO}_{4}$ and $\mathrm{HCl}$, especially when the oxidizer in the form of hydrogen peroxide and ozone was added to the process. These conditions favor the dissolution of metals. The conducted research indicates a large potential of the $\mathrm{PCB}$ leaching method using $\mathrm{HCl}$ and $\mathrm{H}_{2} \mathrm{SO}_{4}$ with the addition of oxidants such as $\mathrm{H}_{2} \mathrm{O}_{2}$ or $\mathrm{O}_{3}$.
\end{abstract}

Keywords: Printed circuit boards, leaching, oxidizing agent, ozone, hydrogen peroxide

\section{INTRODUCTION}

Electrical and electronic waste is becoming an increasing problem in the world. The waste is growing at an alarming rate through continuous technological progress and there are no signs of its slowdown. In addition, they are one of the fastest growing waste streams in the world in terms of quantity. By 2016, the world generated 44.7 million metric tons (Mt) of electronic waste. Only $8.9 \mathrm{Mt}$ of e-waste has been documented worldwide, collected and recycled, which corresponds to $20 \%$ of all electronic waste generated [1]. The diverse composition of electronic scrap has led to the formation of a large stream of hazardous waste, which is associated with the fact that they can pose a threat to both health and life of people, as well as the environment. This type of waste contains heavy metals, polymers, various kinds of organic compounds containing, among others: bromine, chromium, lead and mercury. Thus, recycling of this type of waste has been recognized as the main challenge $[2,3]$. The precious metals contained in electrical and electronic waste provide significant economic benefits, and the recovery of metals from these wastes can, to a certain extent, reduce the total global demand for primary metals production, while limiting the emission of greenhouse gases [3,4]. Recycling of electronic waste also helps reduce the amount of material stored in landfills. An example of a diversified composition of used electrical and electronic devices are computers and mobile phones that contain printed 
circuit boards (PCBs). These plates are the carrier of many metals, including precious metals, which is an attractive option for recycling [5]. Thus, PCBs included in mobile phones cause not only ecological threat, but also serious waste of resources, including copper. The main techniques for recycling electronic waste, including mobile phones, are pyrometallurgical and hydrometallurgical methods combined with mechanical pre-treatment $[6,7]$. However, recently most of the activities related to the recovery of these valuable metal waste concentrate on hydrometallurgical techniques, which are more accurate, predictable, easy to monitor and, what is more important, less energy-intensive compared to pyrometallurgical methods. Hydrometallurgical methods do not require complicated and expensive devices [8-11]. The pre-treatment of used cell phones usually involves manual disassembly (Figure 1), removal of hazardous substances from them and separation of other materials from PCBs. Then, the obtained product is processed by hydrometallurgical methods [12].

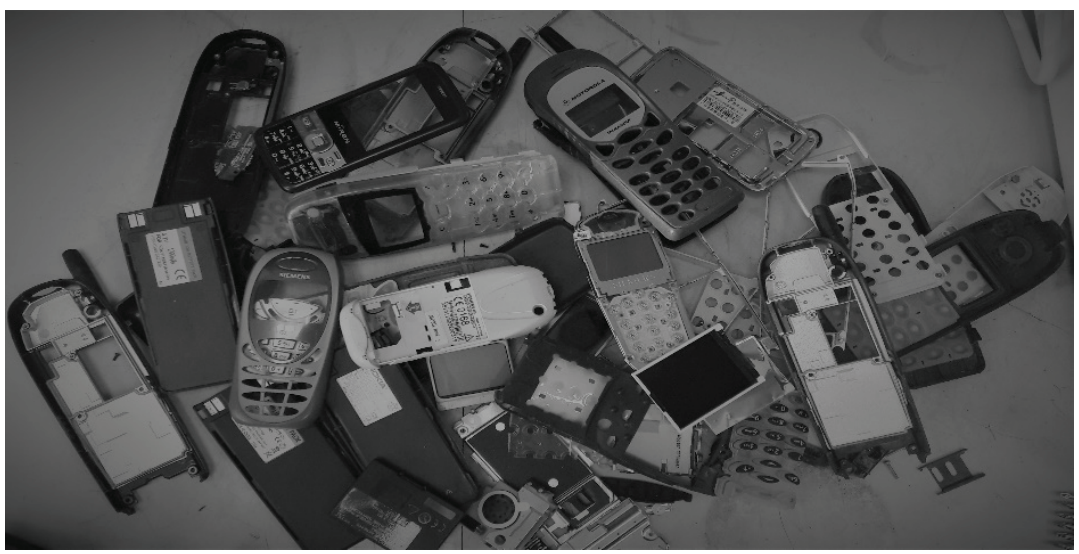

Figure 1 Parts of mobile phones after manual disassembly

Leaching reagents used for the recovery of metals in this method are, among others, acids. Most often, $\mathrm{H}_{2} \mathrm{SO}_{4}$, $\mathrm{HCl}$ and $\mathrm{HNO}_{3}$ or combinations thereof were used. In order to increase the efficiency of the leaching process, additional oxidizing agents were used [13-15]. An example are PCB leaching processes using $\mathrm{H}_{2} \mathrm{SO}_{4}$ with the addition of hydrogen peroxide, obtaining satisfactory copper recovery results from these wastes (85-99\%) $[9,10,16,17]$. Another example is the use of ozone, which is known as one of the strongest oxidizers in acidic solutions $[16,18,19]$. Such an oxidant can be a viable alternative that gives a number of environmental benefits in the leaching of concentrates and wastes that contain metals, including precious metals, mainly due to the formation of oxygen as the only by-product of the reaction. Ozone was used in hydrometallurgical processes by many researchers. It was used, among others, as an oxidizer in combination with hydrochloric acid in the leaching of stibnite concentrates [18], leaching of tetrahedrite [20], leaching of a complex sulfidic antimony ore in hydrochloric acid solution [21], silver leaching from pyrargyrite [19], chalcopyrite leaching [22-24] and leaching metallic waste containing silver [25].

\section{EXPERIMENTAL METHODOLOGY}

Spent mobile phones of different producers were used as a material for research. Manual dismantling of them were carried out separating their particular elements (such as casing, battery, screens and others) from the printed circuit boards. The printed circuit boards were cut into pieces of $20-30 \mathrm{~mm}$ and then the pieces was milled in the cross beater Retsch SK100 hammer mill. Materials were prepared in such way as then leached. The experiments were carried out in a $600 \mathrm{ml}$ flask using $2 \mathrm{M}$ sulfuric acid and $2 \mathrm{M}$ hydrochloric acid as a leaching agent with the addition of ozone and $30 \%$ hydrogen peroxide. Ozone was produced, in concentration $140 \mathrm{mg} / \mathrm{L}$ and a volume of feed gas $8 \mathrm{~L} / \mathrm{min}$, by generator Korona L20 SPALAB. The process was conducted in the temperature range of $313 \mathrm{~K}$ and $353 \mathrm{~K}$, providing mixing of the system with a mechanical stirrer of 400 $\mathrm{rpm}$. The leaching process was carried out under continuous stirring for $6 \mathrm{~h}$ and then each sample was left for 
another $18 \mathrm{~h}$ under static conditions without further stirring. Tests were carried out for a constant ratio of solids to liquid $(S / L=1: 4)$. During experiments the concentration of $\mathrm{Cu}, \mathrm{Fe}, \mathrm{Zn}, \mathrm{Al}, \mathrm{Sn}$ and $\mathrm{Ni}$ was constantly monitored after time: $2 \mathrm{~h}, 6 \mathrm{~h}, 10 \mathrm{~h}$ and $24 \mathrm{~h}$. Content of metals in the sample was determined by the atomic adsorption spectrometry (AAS). Figure 2 presents the scheme of the conducted research.

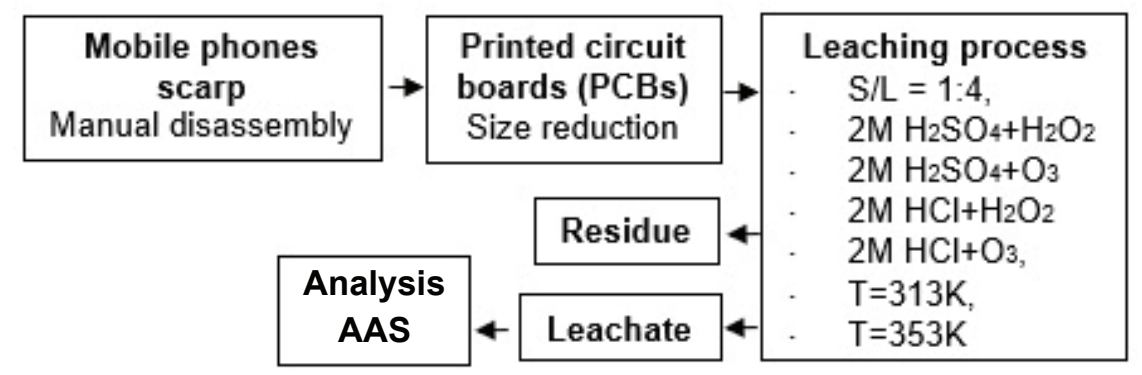

Figure 2 Scheme of the conducted research (stages of leaching process of PCBs)

\section{RESEARCH RESULTS}

Figure 3 shows the effect of copper concentration changes over 24 hours leaching in $2 \mathrm{M}$ sulfuric acid and $2 \mathrm{M}$ hydrochloric acid and the addition of ozone and hydrogen peroxide at $313 \mathrm{~K}$ and $353 \mathrm{~K}$. The dissolution rate of copper was dependent on the temperature in the case of sulfuric acid. Already after $6 \mathrm{~h}$ of the experiment an increase in $\mathrm{Cu}$ concentration at $353 \mathrm{~K}$ was observed, amounting to $21.48 \mathrm{~g} / \mathrm{dm}^{3}$ (for $\mathrm{H}_{2} \mathrm{SO}_{4}+\mathrm{H}_{2} \mathrm{O}_{2}$ ) and $15.82 \mathrm{~g} / \mathrm{dm}^{3}$ (for $\mathrm{H}_{2} \mathrm{SO}_{4}+\mathrm{O}_{3}$ ). After $10 \mathrm{~h}$ of the experiment it was obsreved the decrease in copper concentration by almost $4 \mathrm{~g} / \mathrm{dm}^{3}$ by the end of the experiment (for $\mathrm{H}_{2} \mathrm{SO}_{4}+\mathrm{H}_{2} \mathrm{O}_{2}$ in $T=353 \mathrm{~K}$ ). The best copper leaching results during 24-hour leaching were obtained with $2 \mathrm{M} \mathrm{HCl}+\mathrm{O}_{3}$ at $313 \mathrm{~K}$ and $353 \mathrm{~K}$, corresponding to 26.22 $\mathrm{g} / \mathrm{dm}^{3}$ and $30.77 \mathrm{~g} / \mathrm{dm}^{3}$, respectively.

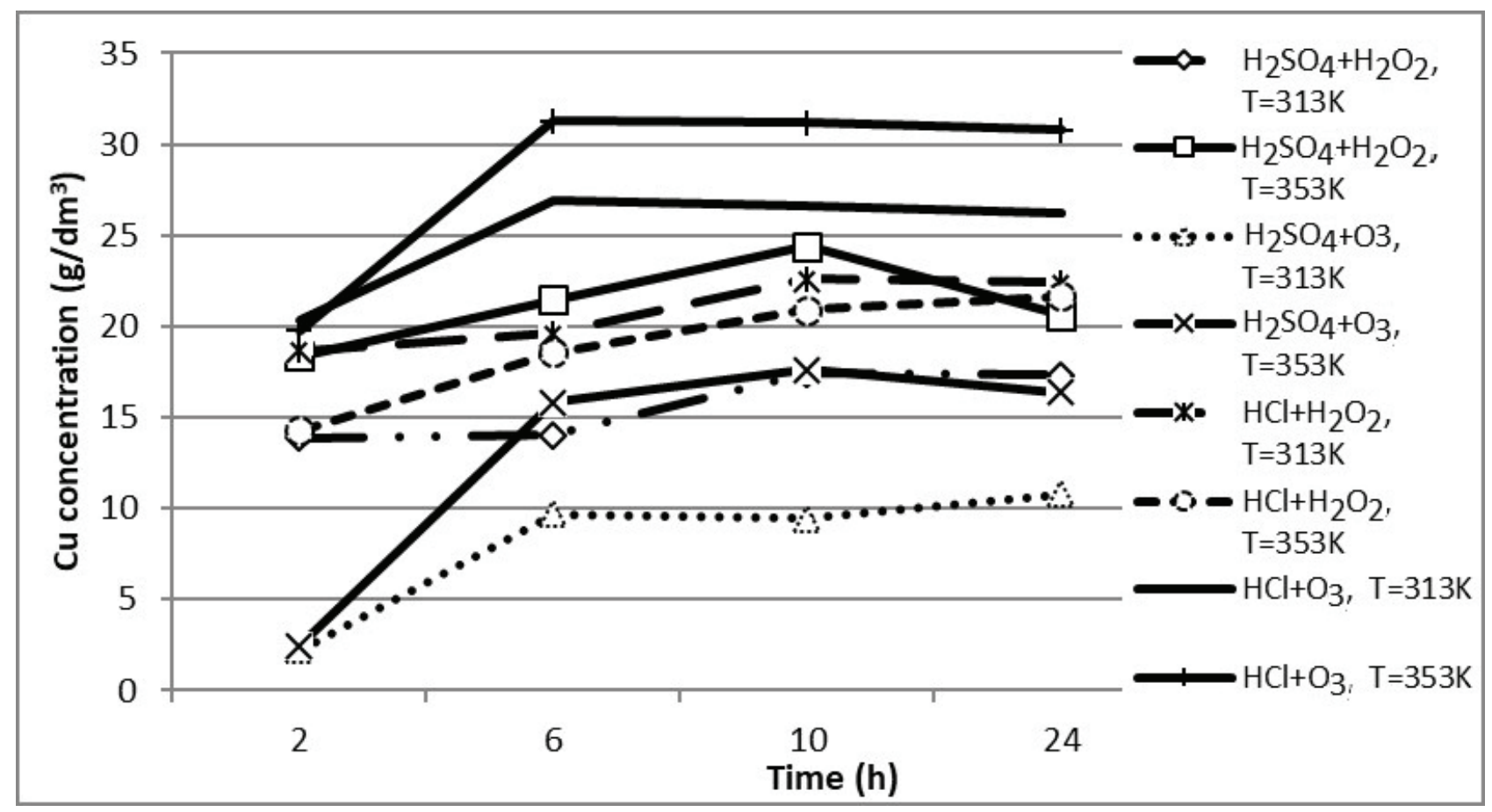

Figure 3 Copper concentration obtained after leaching in $\mathrm{H}_{2} \mathrm{SO}_{4}$ and $\mathrm{HCl}$ with the addition of oxidazer $\left(\mathrm{H}_{2} \mathrm{O}_{2}\right.$ or $\mathrm{O}_{3}$ ) during $24 \mathrm{~h}$ of experiment 
Figure 4 shows a comparison of tin leaching results in $2 \mathrm{M}$ sulfuric acid and $2 \mathrm{M}$ hydrochloric acid with the addition of $30 \%$ hydrogen peroxide and ozone. It can be observed that the hydrogen peroxide works and ozone acts on the tin from the beginning of the experiment in a similar way. This is evidenced by the results obtained. The best results were obtained during 24-hour leaching in $2 \mathrm{M} \mathrm{HCl}+\mathrm{H}_{2} \mathrm{O}_{2}$ at $T=353 \mathrm{~K}$, the $\mathrm{Sn}$ concentration was $9.25 \mathrm{~g} / \mathrm{dm}^{3}$, following $9.24 \mathrm{~g} / \mathrm{dm}^{3}$ in $2 \mathrm{M} \mathrm{H}_{2} \mathrm{SO}_{4}+\mathrm{H}_{2} \mathrm{O}_{2}$ at $T=313 \mathrm{~K}$. Slightly lower results were obtained by adding ozone. After 24-hour experiments with the use of ozone, the concentration of tin was $8.87 \mathrm{~g} / \mathrm{dm}^{3}$ (for $\mathrm{HCl}+\mathrm{O}_{3}$ in $T=313 \mathrm{~K}$ ) and $8.32 \mathrm{~g} / \mathrm{dm}^{3}$ (for $\mathrm{H}_{2} \mathrm{SO}_{4}+\mathrm{O}_{3}$ in $T=353 \mathrm{~K}$ ). The increase in temperature has no effect on tin dissolution in these experiments.

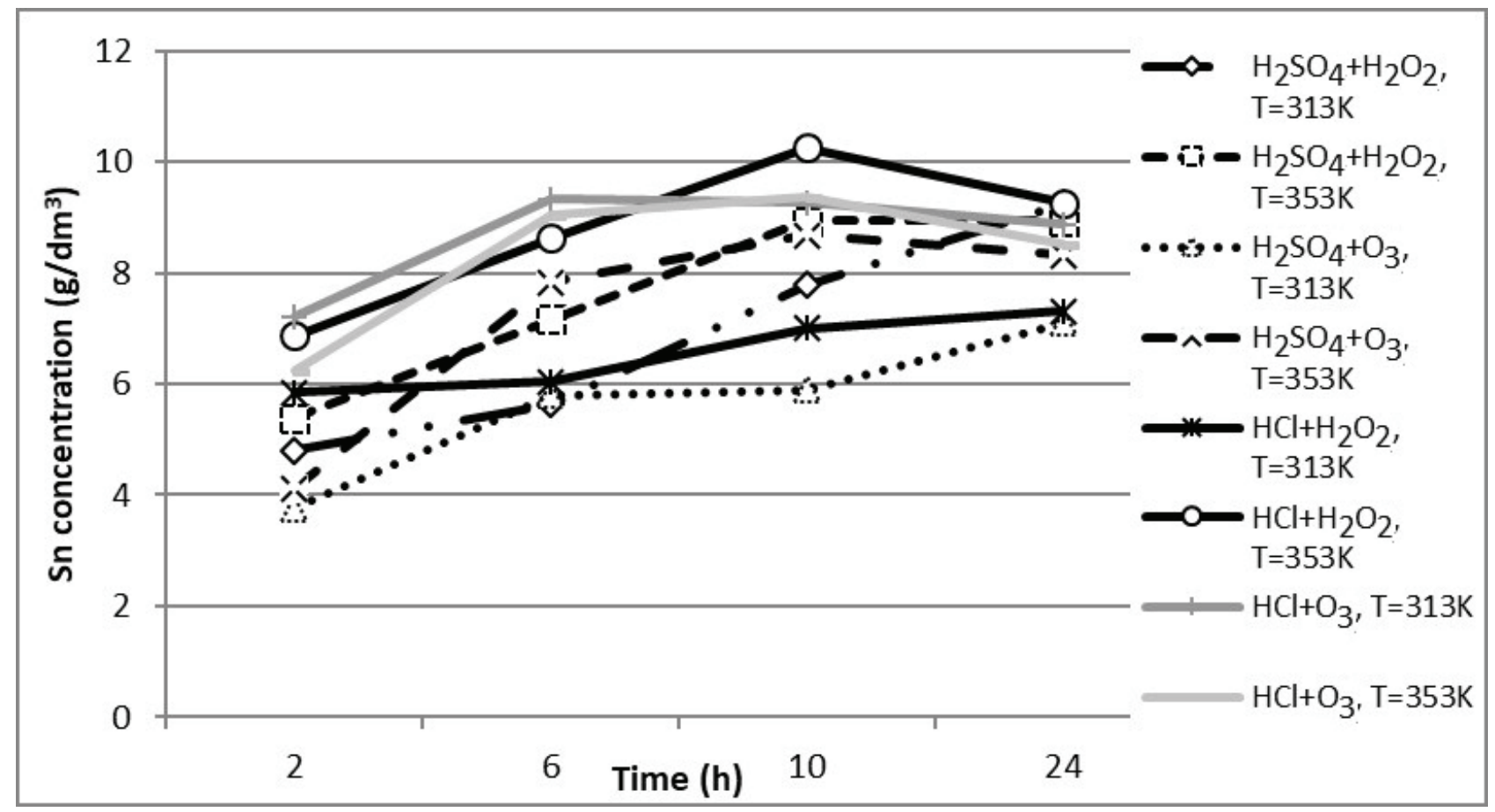

Figure 4 Tin concentration obtained after leaching PCBs in $\mathrm{H}_{2} \mathrm{SO}_{4}$ and $\mathrm{HCl}$ with the addition of oxidizer $\left(\mathrm{H}_{2} \mathrm{O}_{2}\right.$ or $\left.\mathrm{O}_{3}\right)$ during $24 \mathrm{~h}$ of experiment

Figure 5 shows a comparison of the best results of leaching of iron, aluminum and nickel in $2 \mathrm{M}$ sulfuric acid and $2 \mathrm{M}$ hydrochloric acid with the addition of $30 \%$ hydrogen peroxide and ozone. It can be seen that the majority of those selected among the best results come from leaching experiments with the addition of ozone. It can also be observed that the remaining samples under static conditions for a further 14 hours do not significantly affect the increase in nickel, aluminum and iron concentrations. Hydrochloric acid combined with hydrogen peroxide and ozone act on iron from the beginning of the experiment, but the ozone result is slightly lower. After $2 \mathrm{~h}$ it was $6.24 \mathrm{~g} / \mathrm{dm}^{3}$ for $30 \% \mathrm{H}_{2} \mathrm{O}_{2}$ in $T=353 \mathrm{~K}$ and $5.01 \mathrm{~g} / \mathrm{dm}^{3}$ for $\mathrm{O}_{3}$ in $T=313 \mathrm{~K}$. After $24 \mathrm{~h}$, the results were $11.06 \mathrm{~g} / \mathrm{dm}^{3}$ and $8.76 \mathrm{~g} / \mathrm{dm}^{3}$, respectively. In research [14], the effect of sulfuric acid alone and the addition of ozone and hydrogen peroxide was compared for iron, the best result $\left(6.36 \mathrm{~g} / \mathrm{dm}^{3}\right)$ was achieved without the use of an additional oxidizing agent using $\mathrm{H}_{2} \mathrm{SO}_{4}$. The leaching results of $\mathrm{HCl}$ with the addition of hydrogen peroxide are as good as the use of ozone.

The results of iron leaching using hydrogen peroxide and ozone differ slightly. In the case of iron, the addition of hydrogen peroxide and ozone to sulfuric acid and hydrochloric acid had no significant effect on increase in their concentration in solution after the leaching process. After 24 hours of the experiment the aluminum concentration was respectively $7.37 \mathrm{~g} / \mathrm{dm}^{3}, 5.65 \mathrm{~g} / \mathrm{dm}^{3}, 5.30 \mathrm{~g} / \mathrm{dm}^{3}$ (for $2 \mathrm{M} \mathrm{HCl}$ in $353 \mathrm{~K}$ with the addition of ozone, $2 \mathrm{M} \mathrm{H}_{2} \mathrm{SO}_{4}+\mathrm{O}_{3}$ in $353 \mathrm{~K}$ and $2 \mathrm{M} \mathrm{H}_{2} \mathrm{SO}_{4}$ with the addition of $30 \%$ hydrogen peroxide at $353 \mathrm{~K}$ ). The best result was obtained for a solution with ozone. The results of nickel leaching using hydrogen peroxide and 
ozone differ slightly. The best result of nickel concentration after 24 hours of experience amounting to 6.46 $\mathrm{g} / \mathrm{dm}^{3}$ was achieved by using $2 \mathrm{M} \mathrm{HCl}+\mathrm{H}_{2} \mathrm{O}_{2}$ in $T=353 \mathrm{~K}$, immediately after it $5.83 \mathrm{~g} / \mathrm{dm}^{3}$ using $2 \mathrm{M} \mathrm{HCl}+\mathrm{O}_{3}$ in $T=353 \mathrm{~K}$. Only the minimum increase in $\mathrm{Zn}$ concentration after $24 \mathrm{~h}$ of leaching is visible - this concentration was $1.58 \mathrm{~g} / \mathrm{dm}^{3}$, when $\mathrm{HCl}+\mathrm{O}_{3}$ was used in $T=353 \mathrm{~K}$ and $1.27 \mathrm{~g} / \mathrm{dm}^{3}$ in $\mathrm{HCl}+\mathrm{O}_{3} \mathrm{~T}=313 \mathrm{~K}$. Due to the low concentration of $\mathrm{Zn}$ in the solution at the other parameters of the results processes, it has not been shown in the figure.

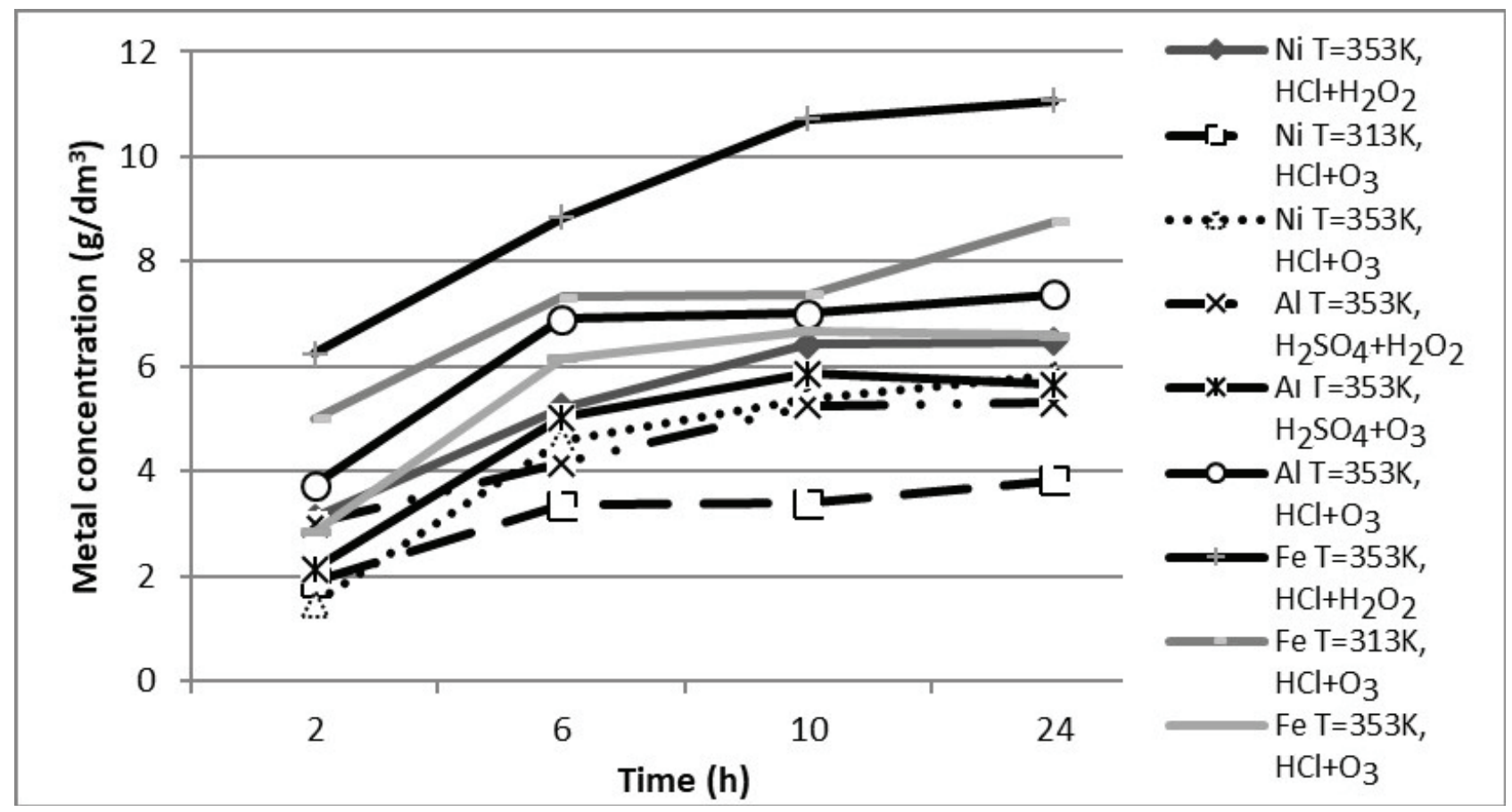

Figure 5 Nickel, aluminum and iron concentration obtained after leaching $\mathrm{PCBs}_{2}$ in $\mathrm{H}_{2} \mathrm{SO}_{4}$ and $\mathrm{HCl}$ with the addition of oxidizer $\left(\mathrm{H}_{2} \mathrm{O}_{2}\right.$ or $\left.\mathrm{O}_{3}\right)$ during $24 \mathrm{~h}$ experiment

\section{CONCLUSION}

To increase the efficiency of the leaching process, strong oxidizing agent should be added to the acid - two of them are hydrogen peroxide and ozone. This is evidenced, inter alia, by the results of tests carried out with the addition of hydrogen peroxide and ozone [7,8,14-19]. Own experiments were carried out using these oxidizing agents. The obtained results showed intensification of the process of leaching printed circuit boards from used cell phones with the use of $\mathrm{H}_{2} \mathrm{SO}_{4}$ and $\mathrm{HCl}$ with the addition of hydrogen peroxide and ozone as an oxidizer. The best results of the copper leaching process were observed for $2 \mathrm{M}$ hydrochloric acid and ozone, the results obtained are around $27 \%$ better than using hydrogen peroxide. The process of tin, iron and nickel leaching was the best when using $\mathrm{HCl}$ and $\mathrm{H}_{2} \mathrm{O}_{2}$, however slightly lower results were obtained with $\mathrm{HCl}$ and $\mathrm{O}_{3}$. For aluminum, the efficiency of this process was best with $\mathrm{HCl}$ and $\mathrm{O}_{3}$. In the case of zinc the addition of hydrogen peroxide and ozone to the sulfuric acid and hydrochloric acid did not substantially influence the increase of their concentration in the solution after leaching process. There is seen only minimal increase of zinc concentration after 24 hours of leaching - this concentration was $1.58 \mathrm{~g} / \mathrm{dm}^{3}$ when $\mathrm{HCl}$ and $\mathrm{O}_{3}$ was used. The obtained positive results indicate the potential of the PCBs leaching method using $\mathrm{O}_{3}$ and are the basis for the continuation of research in this field. The leaching of PCBs with the participation of acid and ozone is new in the country, and the continuation of research will recognize the phenomena occurring in this process and select its appropriate parameters for the effective recovery of copper and associated metals from electronic waste, such as mobile phones. 


\section{ACKNOWLEDGEMENTS}

The research was carried out thanks to the availability of the laboratory at Department of NonFerrous Metals, Refining and Recycling, Faculty of Materials Technology in VSB - Technical University of Ostrava. Authors gratefully acknowledged the support from the research project BK 205/RM0/2019

\section{REFERENCES}

[1] BALDE, C.P., FORTI V., GRAY, V., KUEHR, R. and STEGMANN, P. The Global E-waste Monitor - 2017. United Nations University (UNU), International Telecommunication Union (ITU) \& International Solid Waste Association (ISWA), Bonn/Geneva/Vienna, pp. 4-7.

[2] HEACOCK, M., KELLY, C.B., ASANTE, K.A., BIRNBAUM, L.S., BERGMAN, A.L. and BRUNE, M. E-waste and harm to vulnerable populations: a growing global problem. Environmental Health Perspectives. 2015. vol. 124 , no. 5 , pp. 550-555.

[3] KUMAR, A., HOLUSZKO, M. and CROCCE, D. E-waste: An overview on generation, collection, legislation and recycling practice. Resources Conservation and Recycling. 2017. vol. 122, pp.32-42.

[4] WILLNER, J., FORNALCZYK, A. Złom elektroniczny jako źródło metali szlachetnych. Przemysł chemiczny. 2011. vol. 90, no. 11, pp. 517-521.

[5] SATERNUS, M., FORNALCZYK A., WILLNER J. and KANIA H. Methods for silver recovery from by-products and spent materials. Przemyst Chemiczny. 2016. vol. 95, pp. 78-83.

[6] KARDAS, E., BROZOVÁ,S. Situation in waste treatment in Poland. In METAL 2013: 22nd International Conference on Metallurgy and Materials, Brno, 2013. pp. 1773-1778. ISBN: 978-808729441-3

[7] BROŽOVÁ, S. Possibility of using pyrolysis and plasma during disposal of plastic parts of electric waste. In SGEM: International Multidisciplinary Scientific GeoConference Surveying Geology and Mining Ecology Management. Bulgaria, 2013. pp. 423-428. DOI: 10.5593/SGEM2013/BD4/S18.018. ISSN: 13142704

[8] GHOSH, B., GHOSH, M.K., PARHI, P., MUKHERJEE, P.S., MISHRA, B.K. Waste Printed Circuit Boards recycling: an extensive assessment of current status. Journal of Cleaner Production. 2015. vol. 94, pp. 5-19.

[9] CUI, H. and ANDERSON, C.G. Literature Review of Hydrometallurgical Recycling of Printed Circuit Boards (PCBs). Journal of Advanced Chemical Engineering. 2016. vol. 6, no. 1, pp. 1-11.

[10] KAYA, M. Recovery of metals and non-metals from electronic waste by physical and chemical recycling processes. Waste Management. 2016. vol. 57, pp. 64-90.

[11] KHALIQ, A., RHAMDHANI, M. A., BROOKS, G. and MASOOD, S. Metal extraction processes for electronic waste and existing industrial routes: A review and Australian perspective. Resources. 2014. Vol.3, pp. 152-179.

[12] FORNALCZYK, A., WILLNER, J., FRANCUZ K. and CEBULSKI J. E-waste as a source of valuable metals, Archives of Materials Science and Engineering. 2013. vol. 63, no. 2, pp. 87-92.

[13] ABDELBASIR, S.M., HASSAN, S.S.M., KAMEL, A.H. and EL-NASR, R.S. Status of electronic waste recycling techniques: a review. Environmental Science and Pollution Research International. 2018. vol. 25, no. 17, pp. 16533-16547.

[14] DEEPAK, P., DEEPIKA, J., MANOJ, K.U., and RAVINDRA, K.K. Chemical and biological extraction of metals present in E-waste: a hybrid technology. Waste Management. 2012. vol. 32, pp. 979-990.

[15] LISIŃSKA, M., SATERNUS, M., WILLNER, J. Research of leaching of the printed circuit boards coming from waste mobile phones. Archives of Metallurgy and Materials. 2018, vol. 63, no. 1, pp. 143-147.

[16] LISIŃSKA, M., SATERNU, M., WILLNER, J. and FORNALCZYK A. The role of oxidizing agents in the leaching process electronic waste. Archives of Metallurgy and Materials. 2018, vol. 63, no. 2, pp. 963-968.

[17] AKCIL, A., ERUST, C., GAHAN, C., OZGUN, M., SAHIN, M., TUNCUK, A. Precious metal recovery from waste printed circuit boards using cyanide and non-cyanide lixiviants - a review, Waste Management. 2015. vol. 45, pp. 258-271.

[18] TIAN, Q., WANG, H., XIN, Y., YANG, Y., LI, D. and GUO, X. Effect of selected parameters on stibnite concentrates leaching by ozone. Hydrometallurgy. 2016. vol. 165, pp. 295-299. 
[19] RODRIGUEZ-RODRIGUEZ, C., NAVA-ALONSO, F. and URIBE-SALAS, A. Silver leaching from pyrargyrite oxidation by ozone in acid media. Hydrometallurgy. 2014. vol. 149, pp. 168-176.

[20] UKASIK, M. and HAVLIK, T. Effect of selected parameters on tetrahedrite leaching by ozone. Hydrometallurgy. 2015. vol. 77, pp. 139-145.

[21] TIAN, Q., WANG, H., XIN, Y., LI, D. and GUO, X. Ozonation leaching of a complex sulfidic antimony ore in hydrochloric acid solution. Hydrometallurgy. 2016. vol. 159, pp. 126-131.

[22] HAVLIK, T. Microwave leaching of chalcopyrite - possible improvement in Hydrometallurgy. Metall. 2010. vol. 64, no. 5 , pp. 25-28.

[23] HAVLIK, T. and ŠKROBIAN, M. Acid leaching of chalcopyrite in the presence of ozone. Canadian Metallurgical Quarterly. 1990. vol. 29, no. 2, pp. 133-139.

[24] HAVLIK, T., DVORSCIKOVA, J., IVANOVA, Z. and KAMMEL, R. Sulphuric acid chalcopyrite leaching using ozone as oxidant. Metall. 1999, vol. 53, no. 1, pp. 57-60.

[25] VINALS, J., JUAN, E., ROCA, A., CRUELLS, M., CRUELLS, M. and CASADO, J. Leaching of metallic silver with aqueous ozone. Hydrometallurgy. 2005, vol. 76, pp. 225-232. 